NOT JUST THE GREAT CONTRACTION:

FRIEDMAN AND SCHWARTZ'S A MONETARY HISTORY OF THE UNITED STATES 1867 TO 1960

\author{
Michael D. Bordo \\ Hugh Rockoff
}

Working Paper 18828

http://www.nber.org/papers/w18828

\author{
NATIONAL BUREAU OF ECONOMIC RESEARCH \\ 1050 Massachusetts Avenue \\ Cambridge, MA 02138 \\ February 2013
}

Paper prepared for the Session: "The Fiftieth Anniversary of Milton Friedman and Anna J. Schwartz, A Monetary History of the United States", American Economic Association Annual Meetings, San Diego, CA, January 62013 . The views expressed herein are those of the authors and do not necessarily reflect the views of the National Bureau of Economic Research.

NBER working papers are circulated for discussion and comment purposes. They have not been peerreviewed or been subject to the review by the NBER Board of Directors that accompanies official NBER publications.

(C) 2013 by Michael D. Bordo and Hugh Rockoff. All rights reserved. Short sections of text, not to exceed two paragraphs, may be quoted without explicit permission provided that full credit, including (c) notice, is given to the source. 
Not Just the Great Contraction: Friedman and Schwartz's A Monetary History of the United

States 1867 to 1960

Michael D. Bordo and Hugh Rockoff

NBER Working Paper No. 18828

February 2013

JEL No. B22,N1

\begin{abstract}
A Monetary History of the United States 1867 to 1960 published in 1963 was written as part of an extensive NBER research project on Money and Business Cycles started in the 1950s. The project resulted in three more books and many important articles. A Monetary History was designed to provide historical evidence for the modern quantity theory of money. The principal lessons of the modern quantity theory of the long-run neutrality of money, the transitory effects of monetary policy on real economic activity, and the importance of stable money and of monetary rules have all been absorbed in modern macro models. A Monetary History, unlike the other books, has endured the test of time and has become a classic whose reputation has grown with age. It succeeded because it was based on narrative and not an explicit model. The narrative methodology pioneered by Friedman and Schwartz and the beautifully written story still captures the imaginations of new generations of economists.
\end{abstract}

Michael D. Bordo

Department of Economics

Rutgers University

New Jersey Hall

75 Hamilton Street

New Brunswick, NJ 08901

and NBER

bordo@econ.rutgers.edu

Hugh Rockoff

Department of Economics

75 Hamilton Street

Rutgers University

College Avenue Campus

New Brunswick, NJ 08901-1248

and NBER

rockoff@fas-econ.rutgers.edu 


\section{Not Just the Great Contraction: Friedman and Schwartz's A Monetary History of the United States 1867 to $1960^{1}$}

Milton Friedman and Anna J. Schwartz (afterwards FS) published A Monetary History of the United States 1867 to 1960 (afterwards AMH) with Princeton University Press in 1963 to critical acclaim. Many leading economists of the day including Sir Roy Harrod, James Tobin, Robert Clower, Karl Brunner and Allan Meltzer wrote glowing reviews but all of course had issues of disagreement. Its contribution after twenty five years was assessed in an NBER conference in honor of Anna Schwartz (Bordo 1989) and after thirty years in a Symposium of the Journal of Monetary Economics (1994) with articles by Robert Lucas, Jeffrey Miron and Bruce Smith.

The book has been heavily cited by economists, economic historians, journalists and policy makers since its publication. Indeed Ben Bernanke, then a Governor of the Fed told Milton Friedman at his $90^{\text {th }}$ birthday party at the University of Chicago "I would like to say to Milton and Anna: Regarding the Great Depression. You're right. We did it. We're very sorry. But thanks to you, we won't do it again" (Bernanke 2002b). He was referring to the indictment of the Fed in chapter 7 of AMH for causing the Great Contraction of 1929 to 1933 by not using their policy tools to offset four devastating banking panics from 1930-1933. The book is easily one of the most influential volumes in economics in the twentieth century.

The collaboration by FS that led to AMH was part of the NBER's project on Money and Business Cycles started in the 1950s. This project resulted in two more books by FS: Monetary Statistics of the United States (1970) and Monetary Trends in the United States and United Kingdom (1982), several important articles including "Money and Business Cycles" (1963a) and Philip Cagan's The Determinants and Effects of Changes in the Stock of Money (1965). This project fit solidly into the Bureau tradition which emphasized the gathering of new data, particularly monthly data. One of the most enduring products of the project was FS's new estimates of the stock of money. These estimates have been widely used by both supporters and critics of the story told in AMH, and by macro-economists exploring completely different

\footnotetext{
${ }^{1}$ We thank Allan Meltzer for his comments on an earlier draft and Nga Nguyen for her research assistance.
} 
avenues of research. The Bureau tradition, reflecting the views of its founder Wesley Clair Mitchell, moreover, stressed that the business cycle was a complex product of numerous factors that had to be investigated one by one by a collective of scholars. Friedman and Schwartz's assignment, so to speak, was to tease out the effects of money on the business cycle (Rockoff 2010).

The theoretical background for the project was Friedman's "Restatement of the Quantity Theory of Money" (1956) which was intended to be a counterfoil to the then prevailing Keynesian paradigm. At the time, a common, although by no means universal, view among Keynesian economists was that monetary policy had very little influence on the economy. Increases in the money supply might lower interest rates, but only a bit, and lower interest rates might stimulate investment spending, but only a bit. Any correlation between money and economic activity reflected mainly a causal path from income to money or a common third factor that affected both. AMH changed the way most economists thought about monetary policy. What came to be called the Neo-Keynesian consensus put considerable weight on monetary policy and owed a great deal to $\mathrm{AMH}$.

The key propositions of the modern quantity theory were that: based on the interaction between a stable long run demand for money and an independently determined money supply, a change in the rate of growth in the money supply would produce a corresponding but lagged change in the growth of nominal income. In the short-run changes in money would produce changes in real output; in the long run changes in money would be fully reflected in changes in the price level. In modern terms, monetary changes would temporarily impact real output reflecting nominal rigidities but ultimately the growth of real output is independent of monetary forces and monetary neutrality would prevail.

AMH was designed to provide long-run historical evidence for the modern quantity theory (with the underlying statistics presented in Monetary Statistics), Money and Business Cycles was to provide short-run cycle evidence, and Monetary Trends was to provide long-run econometric evidence. Of all these efforts only AMH and Monetary Statistics have survived the test of time. 


\section{The Narrative Approach}

Milton Friedman outlined the methodology that he and Anna Schwartz would employ in AMH what has come to be called "the narrative approach" - in his classic paper "The Methodology of Positive Economics (1953)." To illustrate the importance of natural experiments Friedman $(1953,11)$ turned to monetary history:

"Occasionally, experience casts up evidence that is about as direct, dramatic, and convincing as any that could be provided by controlled experiments. Perhaps the most obviously important example is the evidence from inflations on the hypothesis that a substantial increase in the quantity of money within a relatively short period is accompanied by a substantial increase in prices. Here the evidence is dramatic, and the chain of reasoning required to interpret it is relatively short. Yet, despite numerous instances of substantial rises in prices, their essentially one-to-one correspondence with substantial rises in the stock of money, and the wide variation in other circumstances that might appear to be relevant, each new experience of inflation brings forth vigorous contentions, and not only by the lay public, that the rise in the stock of money is either an incidental effect of a rise in prices produced by other factors or a purely fortuitous and unnecessary concomitant of the price rise."

The phrase "wide variation in other circumstances that might appear to be relevant" deserves attention. In any one inflationary episode there will be non-monetary forces at work that some observers will claim caused the inflation: wartime mobilization, government deficits, union militancy, shocks to the supply of crucial raw materials, and so on. The economist needs to examine those factors, and see how they varied across historical episodes. If the generalization that money causes inflation holds across episodes, even as other factors vary, there is compelling evidence for it. The quotation also illustrates another hallmark of Friedman's methodology: the importance of a "short chain of reasoning." The goal of science is to explain much with little; Occam's razor must be wielded ruthlessly. Thus, Friedman's essay anticipates the main mission of AMH: to show that in a long series of examples, stretching across very different monetary regimes, the relationships between money, prices, and output suggested by basic economic theory continue to hold.

An overview of some of the evidence that is examined in AMH can be seen in Figure 1 which compares the rate of change of money per unit of output and the rate of change of prices in 11 monetary regimes stretching from the end of the Civil War to 2012. During the greenback 
era from the end of the Civil War until 1879 the United States was on a floating exchange rate. The growth of high powered money was determined internally. And the rate was low because the federal government followed a policy of letting the economy "grow up to the currency." The resulting deflation was necessary so that the United States could rejoin the gold standard at the prewar parity. Once the United States returned to gold, the sources of the increase in the stock of money were different. Under the gold standard the stock of high-powered money was the product of net international transactions and domestic mining. From 1879 until 1896 the money supply grew relatively slowly producing a mild deflation. Then the supply of gold increased due to discoveries in a number of countries, most importantly South Africa, and the development of the new cyanide process for extracting gold from ore, a crucial development for the South African industry: clearly exogenous shocks that the narrative approach was able to identify. The acceleration in the growth rate of money was not dramatic, but was sufficient to turn a secular decline in prices into a secular advance. This was a persuasive natural experiment: an increase in the stock of money that was unplanned by any government authority, but rather the result of exogenous events, had produced the consequences predicted by the quantity theory of money.

With the founding of the Fed in 1913, the monetary system changed again. Now, the amount of high-powered money was controlled by the Fed. Gold flows could affect the stock, but the Fed had considerable power to neutralize those flows. During World War I, the Fed became subservient to the Treasury, buying debt in order to keep nominal interest rates low and stable. The same was true in World War II, and the two wars together became further grist for the mill (Friedman 1952; AMH 1963b, 567-71). As shown in Figure 1, inflation proceeded at a somewhat slower pace in World War II than in World War I. Yet World War II was by many measures the more intense conflict: the period of active engagement was longer, the casualty rate was higher, and federal deficits were larger relative to GDP. Part of the difference between the wars was that money per unit of output grew more slowly in World War II than in World War I for a variety of reasons related to the behavior patterns of the banks and the public with respect to money. In the last period examined in AMH, which we have designated Postwar in figure 1, the United States returned to a regime of slow growth in money per unit of output and inflation.

We have added three regimes that were not covered in AMH: the Great Inflation (196582), the Great Moderation (1982-2008), and the Great Recession (2008-2012). The Great Inflation was the product of a number of factors; an important part of the story was a change in 
policy objectives at the Fed that made achieving and maintaining low unemployment the top priority. This policy was reversed under Fed Chairman Paul Volcker. Slower monetary growth per unit of output during the Great Moderation appears to have contributed to the slowing of inflation from about 6 per cent per year from 1965 to 1982 to about 2.5 percent per year from 1982 to 2008 . The monetary regime changed because the Fed was persuaded to put greater emphasis on price stability. The main reason was that the public was frightened by inflation and demanded action to stop it. But some of the credit for the change in the policy regime must go to the monetarists and to AMH. Figure 1 includes the Great Recession (2008 to 2012) in order to contrast it with the Great Depression. One can see immediately that over the course of the Great Depression money per unit of output grew at a very low rate and that prices declined. During the Great Recession money per unit of output has grown far more rapidly and inflation has continued despite the economic slowdown. Most likely the greater increase in the stock of money relative to output helps account for the relative mildness of the Great Recession. Again the improvement in policy rests in part on the lessons taught by $\mathrm{AMH}$.

AMH discusses many natural experiments that occurred over shorter intervals than a "monetary regime." The sharp increases in the Fed's discount rate in 1920, when the Fed tried to end inflation; in 1928, when the Fed tried to discourage stock market speculation; and in 1931, when the Fed jacked up the discount rate to protect its gold reserves while ignoring a banking panic; in each case undermining the economy, are important examples. Another example that has garnered considerable attention in recent years was the decision by the Fed to double required reserves in a series of steps in 1936-37 in order, the Fed believed, to lock up potentially inflationary excess reserves (AMH 1963b, 520-7). AMH (1963b, 544) concluded that the decline in the stock of money that resulted from this decision - and the "equally important" Treasury gold-sterilization program - "significantly intensified the severity of the decline [in economic activity] and also probably caused it to occur earlier than otherwise." Of course, it was not a laboratory experiment. For one thing, fiscal policy was also changing. Taxes increased, partly because the new Social Security Tax came on line; and spending declined, mainly because the one-time veteran's bonus ran its course. As a result, the budget deficit fell from 4.4 billion in 1936 to 1.2 billion in 1938 (Carter et al 2006, series Ea586). But the episode was, nevertheless, another piece of evidence consistent with the view that money matters. 
AMH is usually remembered today because of chapter 7, The Great Contraction, in which the authors carefully show how the Fed, which was designed to prevent a repeat of the banking panics of the National Banking era, failed to prevent four major banking panics from producing a monetary collapse leading to the worst recession in U.S. history. Some readers of chapter 7 have been frustrated by what seemed to them to be an attempt by AMH to assume the relationship between monetary events and the severity of the Depression rather than to prove it. But a causal relationship between money and income cannot be established in one chapter about one period in monetary history. One set of natural experiments, however suggestive, cannot prove that money matters; the proof comes from the weight of all the evidence. That evidence includes some experiments that fell within the period 1929-1939, but many more that fell outside it.

AMH, we should emphasize, did not espouse a monocausal explanation of the business cycle. In the course of their narrative FS drew attention to many non-monetary factors that they believed had influenced the business cycle, although they did not investigate them systematically across time. For example, FS $(1963 b, 307)$ thought that the 1929 stock market crash had "made the decline in income sharper than it otherwise would have been." And in explaining the incompleteness of the recovery in the 1930s, FS turned to a non-monetary explanation that has reemerged recently to explain the slow recovery from the current recession (Ohanian and Taylor 2012). Here they endorsed the view of Kenneth D. Roose (1954) that "Business confidence," and as a result business investment, had been weakened by increased regulation, the expansion of government activities into areas traditionally reserved for private enterprise, measures that threatened the sanctity of private property, Roosevelt's attack on the "economic royalists," and so on (FS 1963b, 495-96).

A wave of research was triggered by Peter Temin's (1976) revival of a Keynesian explanation of the Great Depression In 1976. ${ }^{2}$ Since then a new generation of economic historians have mined the details of chapter 7 unearthing new data sources and revising or reconfirming the old masters (e.g. Calomiris and Mason 2003, Richardson and Troost 2009, Bordo and Landon-Lane 2010).

The key finding of $\mathrm{AMH}$, to sum up, is that the money-income relationship is invariant to changing monetary arrangements and banking structures. Although FS identify an influence from

\footnotetext{
${ }^{2}$ See (Bordo 1986) for a survey of the literature on the Temin debate.
} 
income to money over the business cycle, they argue that the main influence both cyclically and secularly runs from money to nominal income. Of special importance is the evidence they give on monetary disturbances: sharp declines in output were precipitated by sharp reductions in money supply, while episodes of sustained inflation were invariably produced by the growth of money in excess of the growth of real income. In both types of disturbances, the historical record provides instances where inappropriate actions by the monetary authorities were to blame. Thus the Great Contraction of 1929-33 was a consequence of an unprecedented collapse in the stock of money that the Fed could have prevented, while episodes of inflation during the World Wars were products of wartime issues of fiat money.

The narrative approach of AMH took time to gain traction. In his admiring, although also critical review of AMH, James Tobin (1965) conceded that FS had "identified some convincing examples of monetary changes that were clearly independent of contemporary or immediately preceding economic events," and he was "willing to agree that these monetary events contributed in important degree to the economic events which followed." But in later work Tobin (1970) focused on timing evidence as the key data for establishing a causal relationship between money and income. In his reply to Tobin Friedman $(1970,320)$ pointed to the weight that he and Mrs. Schwartz placed on historical evidence. He conceded that "It may be that in the early years of my work on money, I regarded the lead of money at peaks and troughs as decisive evidence of the independent influence of money." But he went on to argue that for at least a decade prior to 1970 he was fully aware of the limitations of timing evidence, and rather was examining such evidence to determine the leads and lags that could be used to formulate policies and make predictions (Friedman 1970, 322). A short and consistent lag would point to leaving monetary policy to the discretion of the Fed; the long and variable lag that FS found pointed toward a monetary rule.

The narrative approach pioneered by AMH to isolate independent sources of monetary change was picked up by later macroeconomists as a way to solve the identification problem in macroeconomic models. In his remarks on Milton Friedman's ninetieth birthday Ben Bernanke (2002b) explained how FS use natural experiments to solve the identification problem in monetary economics, and how after reading AMH as a graduate student at M.I.T. he became hooked on monetary economics and economic history. Romer and Romer (1989), however, are critical of FS for not clearly demarcating their identification strategy and for picking dates which 
may have been tainted by endogenous feedback from the real economy. They extend the FS strategy to the Post World War II era using FOMC minutes to identify episodes of deliberate Fed tightening to offset inflation. Miron (1994) and Lucas (1994) both praise FS for the narrative approach as breathing new life into macroeconomics.

\section{The Continuing Influence of AMH on the Monetary Policy Debate.}

The wide ranging discussions in AMH have been an inspiration to generations of macroeconomists and economic historians. Their discussions of the determinants of the exchange rate under the greenback standard, the possible effects of a switch to a bimetallic regime in the 1890s, the effects of the issue of the Aldrich-Vreeland emergency currency in 1914, the reasons for the decision not to bail out the Bank of United States when it failed in 1930, the experiences of countries that departed sooner from the gold standard during the 1930s compared with countries that adhered for a longer period, and the impact of New Deal financial reforms on the stability of the banking system, to name only a few, have spawned substantial literatures. AMH, moreover, continues to play an important role in recent debates over monetary policy issues. We briefly mention some of them.

The Great Depression versus the Great Recession. The Great Recession of 2007-2009 has been compared to the Great Depression 1929-33. Many argued that the virulent nature of the collapse in real economic activity and its global reach had considerable resonance with the Great Contraction (e.g. Eichengreen and O'Rourke 2009), and the global liquidity panic of 2008 evoked memories of 1931 (e.g. Bordo and James 2010). It was also argued that the Great Recession did not become a Great Contraction because the Fed and other central banks learned the lessons of $\mathrm{AMH}$ and flooded the financial markets with liquidity (Bordo and Landon-Lane 2010).

Banking Panics versus Bank Insolvency. FS in chapter 7 described the first Banking Crisis of the Great Contraction in October 1931 as a panic reflected in a large drop in the public's depositcurrency ratio. It was transmitted from its origin in the Midwest to the rest of the nation by "a contagion of fear". They also refer to the events in the spring of 1931, the fall of 1931, and early 
1933 as banking panics. Temin (1976) and White (1984) argued that the banking crisis of 1930 was really a solvency event driven by the collapse of economic activity since August 1929. This solvency view gained traction in the work of Wicker (1996) and more recently Calomiris and Mason (2003) and Hetzel (2012). Bordo and Landon-Lane (2010) present econometric evidence reconfirming the FS story. In the recent crisis Schwartz (2009) criticized the Fed and other central banks for failing to recognize that the main problem facing the banking system in 2008 was the inability to distinguish solvent from insolvent institutions.

Good versus Bad Deflation. The Fed in 2002-2006 followed a very expansionary monetary policy based on negative deviations of its policy rate from the Taylor Rule (Taylor 2007). It did this because of the fear of the then very low inflation rate spiraling into a 1930s type debt deflation or a Japan in the 1990s style stagnation. Research by Bordo and Filardo (2004) and Bordo, Landon-Lane, and Redish (2008) looked back to the discussion in AMH chapter 3 on the deflation of 1879-1896 when real output grew at a rate as least as rapidly as in the subsequent episode of low inflation of 1897-1914. In that episode classified as Good Deflation, the price decline reflected a positive aggregate supply shift reflecting rapid productivity growth. By contrast the Bad Deflation of the 1930s reflected a collapse in aggregate demand driven by the events described in AMH.

The Zero Lower Bound. Research at the Fed in the early 2000s on the potential challenge for the use of the conventional short-term interest rate policy tool posed by very low inflation and interest rates close to zero has resonance to AMH treatment of the low interest rates in the 1930s in chapter 8 (Eggertson and Woodford 2003; Coenen, Orphanides, and Wieland 2004). By 2008 the zero lower bound constraint on the use of conventional monetary policy was reached. The Bernanke Fed, taking a page from AMH's discussion of the expansionary gold and silver purchase programs of the US Treasury in 1933-34, where FS argued that the Fed itself should have conducted expansionary open market purchases, engaged in a massive unconventional monetary policy action - open market purchases of long term government bonds and mortgage 
backed securities - in December $2009^{3}$. Some argue that these actions may have attenuated the contraction (Hetzel 2012).

Rules versus Discretion. Friedman (1959), following a long Chicago tradition, made the case for following his constant money growth rate rule rather than central bank discretion. The experience of the Great Contraction described in $\mathrm{AMH}$, as well as many other episodes where Fed stabilization policy backfired, provides historical evidence for his case. Warburton (1966) and later Bordo, Choudhri, and Schwartz (1995) and McCallum (1990) demonstrated how following a Friedman style monetary rule would have avoided most of the Great Contraction.

Fiscal Dominance. In the recent financial crisis the Fed engaged in discount window policies referred to by Goodfriend (2012) as credit policies. It also worked closely with the Treasury in the bailouts of both financial and non-financial firms. These operations are examples of fiscal rather than monetary policy. FS in AMH chapters 8 and 9 analyze the experience of the 1930s and 1940s when the Fed lost its independence and the Fed followed a low interest rate policy at the Treasury's behest. The Fed became an engine of inflation which only ended when its independence was restored after the 1951 Fed-Treasury Accord. There is concern that these events may be repeated.

Expectations. There are many instances in $\mathrm{AMH}$ where the state of expectations is a key determinant of economic outcomes. The best example is the analysis in chapter 3 of the impact of the Free Silver Movement. The Bland Allison Act of 1878 and the Sherman Silver Purchase Act of 1893 were feared by many to be precursors of inflation because the US would be forced off the gold standard. The outcome according to FS was more deflation than would otherwise have been the case triggered by capital flight. The FS analysis in this episode has resonance with the peso problem in the literature on emerging market financial crises in the 1980s and 1990s (See Hallwood, Marsh and Macdonald 2000).

Other Issues. Many important issues relevant to current policy are not covered in AMH although they are treated by FS in later work. Chief among these issues are the Phillips Curve Tradeoff which was the subject of Friedman's famous 1968 AEA lecture and the distinction

${ }^{3}$ FS did not explicitly discuss unconventional monetary policy action. Friedman's (1969) discussion of a helicopter dropping money has been used to justify such actions (Bernanke 2002a). 
between nominal and real interest rates which had a prominent place in Monetary Trends. Friedman's case against the gold standard is also not dealt with directly in AMH but was in $A$ Program for Monetary Stability (1959) and in his essay on "Real Versus Pseudo Gold Standards" (1961).The issue of free banking versus central banking is also not explicitly discussed by FS in AMH but appeared in their 1986 JME article. Friedman's case against Keynesian economics, which is largely based on the evidence in $\mathrm{AMH}$, is also developed later in his work with David Meiselman (1965) and in his debate with his critics in Gordon (1974). Thus, in many respects $\mathrm{AMH}$, and subsequent work by FS based on $\mathrm{AMH}$, are like the Bible. If you look hard enough you can find insightful references to most of the salient issues in modern macroeconomics.

\section{Conclusion}

$\mathrm{AMH}$ is a classic whose reputation has grown with age. It was written as part of a research program which involved several other major books and journal articles. All of the other publications have been virtually forgotten. Why has AMH endured? We think the answer is that AMH is based on narrative and not an explicit model. It was designed to provide evidence for the modern quantity theory of money. The principle lessons of the modern quantity theory of the long run neutrality of money, the transitory effects of monetary policy on real activity, and the importance of stable money and of monetary rules have all been absorbed in modern macro models. Indeed the narrative methodology pioneered by FS and the beautifully written story still capture the imaginations of new generations of economists. Its lessons, especially in chapter 7, have also influenced modern central bankers. As Lucas $(1994,8)$ said "If I ever go to Washington for some other reason than viewing cherry blossoms, I will pack my copy of AMH and leave the rest of my library — well most of it—at home". In the recent crisis it seems that many of our policy makers followed his advice but not fully. 
Figure 1. Rates of change of money per unit of output and prices in 11 monetary regimes.

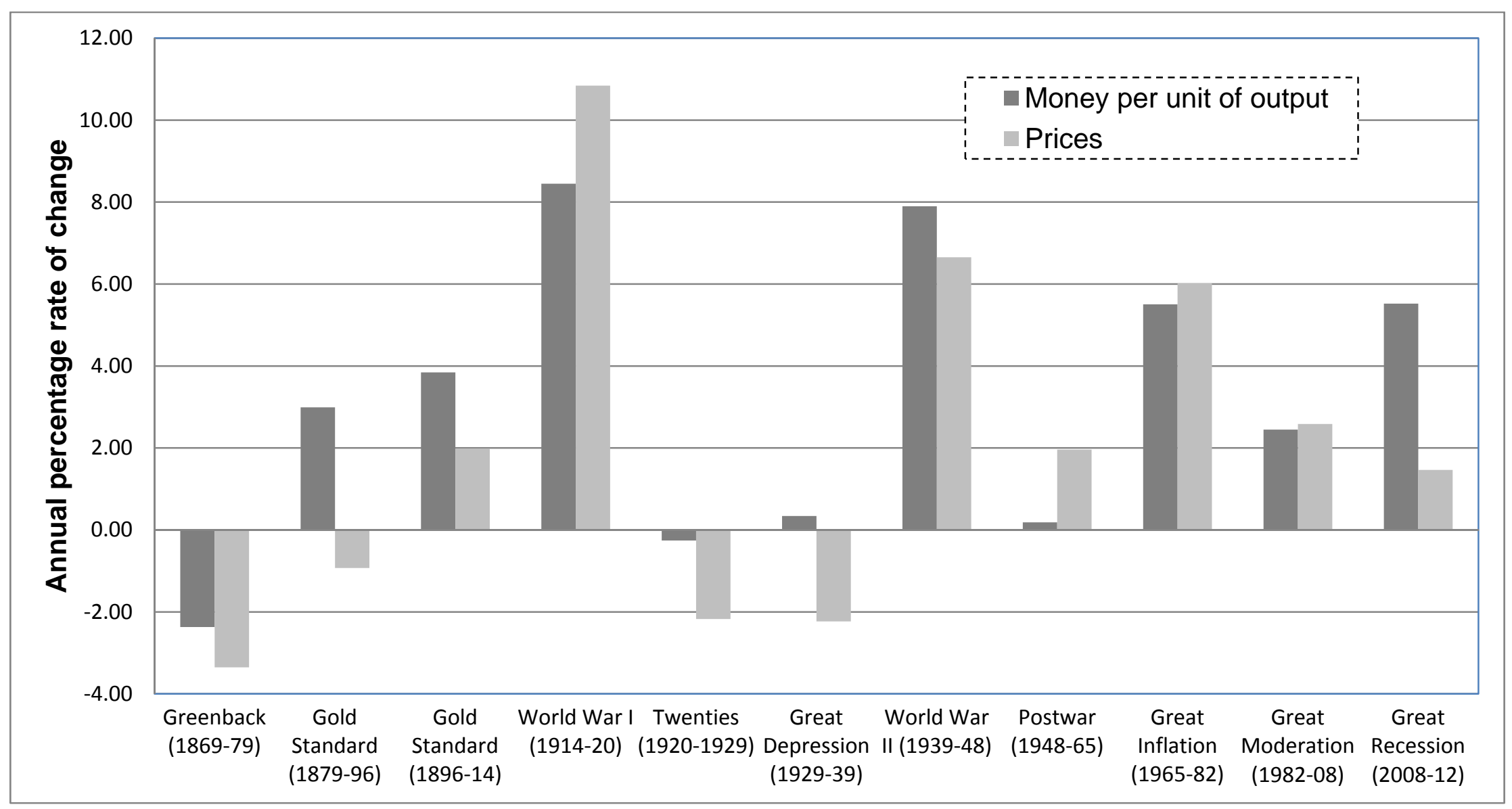

Sources: Money (M2), 1869-1975, FS 1982, table 4.8, column 1; 1965-1980, Carter et al. 2006, series Cj88; 1981-2012, Federal Reserve Bank of St. Louis, FRED, accessed December 2012. Output: 1869-1965, real national income, FS 1982, table 4.8, column 3; 1965-2012, real GDP, billions of chained 2005 dollars, FRED, December 2012. Prices: 1869-1965: national income implicit price deflator, $1929=100$, FS 1982, table 4.8, column 4; 1965-2012, GDP implicit price deflator, $2005=100$, FRED, December 2012 


\section{References}

Bernanke, Ben S. 2002a. Deflation: making sure "It" doesn't happen here. Federal Reserve Board of Governors, November 21.

-2002b. Remarks by Governor Ben S. Bernanke at the Conference to Honor Milton Friedman, University of Chicago, Federal Reserve Board of Governors, November 8.

-1983. Nonmonetary effects of the financial crisis in the propagation of the Great Depression. American Economic Review 73 (3) (06): 257-76.

Bordo, Michael D. 1989. The contribution of A Monetary History of the United States, 18671960 to monetary history. In Money, History and Finance: Essays in Honor of Anna J. Schwartz, ed. Michael D. Bordo, 15-70. Chicago and London: University of Chicago Press for the NBER.

- 1986. Explorations in monetary history: A survey of the literature. Explorations in Economic History 23 (4) (10): 339-415.

Bordo, Michael D., Ehsan U. Choudhri, and Anna J. Schwartz. 1995. Could stable money have averted the Great Contraction? Economic Inquiry 33 (3) (07): 484-505.

Bordo, Michael D., and Harold James. 2010. The past mirror: Notes, surveys, debates: The Great Depression analogy. Financial History Review 17 (2) (10): 127-40.

Bordo, Michael D., and John Landon-Lane. 2010. The banking panics in the United States in the 1930s: Some lessons for today. Oxford Review of Economic Policy 26 (3) (autumn): 486509.

Bordo, Michael D., John Landon-Lane, and Angela Redish. 2010. Deflation, productivity shocks and gold: Evidence from the 1880-1914 period. Open Economies Review 21 (4) (09): 51546. 
Bordo, Michael D., and Andrew Filardo. 2005. Deflation and monetary policy in a historical perspective: Remembering the past or being condemned to repeat it? Economic Policy (44) (10): 799-836, 840-44.

Cagan, Phillip. 1965. Determinants and effects of changes in the stock of money, 1875-1960. Studies in business cycles. Vol. 13. New York: National Bureau of Economic Research; distributed by Columbia University Press.

Calomiris, Charles W., and Joseph R. Mason. 2003. Fundamentals, panics, and bank distress during the Depression. American Economic Review 93 (5) (12): 1615-47.

Carter, Susan B., Scott Sigmund Gartner, Michael R. Haines, Alan L. Olmstead, Richard Sutch, and Gavin Wright. 2006. Historical statistics of the United States: Earliest times to the present. Millennial Edition. New York: Cambridge University Press.

Coenen, Gunter, Athanasios Orphanides, and Volker Wieland. 2004. Price stability and monetary policy effectiveness when nominal interest rates are bounded at zero. Advances in Macroeconomics, v. 4, (1): 1-23.

Eggertson, Gauti and Michael Woodford 2003. The Zero Interest Rate Bound and Optimal Monetary Policy. Brookings Papers on Economic Activity, v.1, 139-211.

Eichengreen, Barry, and Kevin O'Rourke. 2009. A tale of two depressions. http://www.voxeu.org/.

Federal Reserve Bank of St. Louis. FRED economic data. 2012 [cited December 2012]. http://research.stlouisfed.org/fred2/.

Friedman, Milton. 1969. The Optimum Quantity of Money. In The Optimum Quantity of Money and Other Essays, 1-50. Chicago: Aldine Publishing Company.

. 1968. The role of monetary policy. American Economic Review 58 (03): 1-17.

. 1961. Real and pseudo gold standards. Journal of Law and Economics 4 (10): 66-79. 
— 1959. A program for monetary stability. The Millar lectures. Vol. 3. New York:

Fordham University Press.

- 1956. The quantity theory of money - a restatement. In Studies in the quantity theory of money, ed. Milton Friedman, 3-21. Chicago: University of Chicago Press.

- 1953. The methodology of positive economics. In Essays in positive economics, ed. Milton Friedman, 3-42. Chicago and London: University of Chicago Press.

1952. Price, income, and monetary changes in three wartime periods. The American Economic Review 42 (2, Papers and Proceedings of the Sixty-fourth Annual Meeting of the American Economic Association) (May): 612-25.

Friedman, Milton, and David Meiselman. 1965. Reply to Ando and Modigliani and to DePrano and Mayer. The American Economic Review 55 (4) (Sep.): 753-85.

Friedman, Milton, and Anna J. Schwartz. 1986. Has government any role in money? Journal of Monetary Economics 17 (1) (01): 37-62.

-1982. Monetary trends in the United States and the United Kingdom: Their relation to income, prices, and interest rates, 1867-1975. National Bureau of Economic Research monograph. Chicago: University of Chicago Press.

1970. Monetary statistics of the United States: Estimates, sources, methods. National Bureau of Economic Research. Studies in business cycles. Vol. 20. New York: National Bureau of Economic Research.

- 1963a. Money and business cycles. The Review of Economics and Statistics 45 (1, Part 2, Supplement) (Feb.): 32-64.

1963b. A monetary history of the United States, 1867-1960. National Bureau of Economic Research. Studies in business cycles. Vol. 12. Princeton: Princeton University Press. 
Goodfriend, Marvin. 2012. The elusive promise of independent central banking. Bank of Japan Monetary and Economic Studies (November): 39-54.

Gordon, Robert J. 1974. Milton Friedman's monetary framework: A debate with his critics. Chicago: University of Chicago Press.

Hallwood, C. P., Ronald MacDonald, and Ian W. Marsh. 2000. Realignment expectations and the US dollar, 1890-1897: Was there a 'peso problem'? Journal of Monetary Economics 46 (3) (12): 605-20.

Hetzel, Robert L. 2012. The Great Recession: Market failure or policy failure? Cambridge: Cambridge University Press.

Lucas, Robert E., Jr. 1994. Review of Milton Friedman and Anna J. Schwartz's 'A Monetary History of the United States, 1867-1960.' Journal of Monetary Economics 34 (1) (08): 5-16.

McCallum, Bennett T. 1990. Could a monetary base rule have prevented the Great Depression? Journal of Monetary Economics 26 (1) (08): 3-26.

Miron, Jeffrey A. 1994. Empirical methodology in macroeconomics: Explaining the success of Friedman and Schwartz's 'A Monetary History of the United States, 1867-1960.' Journal of Monetary Economics 34 (1) (08): 17-25.

Ohanian, Lee and John B. Taylor 2012. Government Policies and the Delayed Economic Recovery. Stanford: Hoover Institution Press.

Richardson, Gary, and William Troost. 2009. Monetary intervention mitigated banking panics during the Great Depression: Quasi-experimental evidence from a Federal Reserve district border, 1929-1933. Journal of Political Economy 117 (6) (12): 1031-73.

Rockoff, Hugh. 2010. On the origins of A Monetary History. In The Elgar companion to the Chicago school of economics, ed. Ross B. Emmett, 81-113. Cheltenham, U.K.: Edgar Elgar. 
Romer, Christina D., and David H. Romer. 1989. Does monetary policy matter? A new test in the spirit of Friedman and Schwartz. In NBER Macroeconomics Annual, eds. Olivier Jean Blanchard and Stanley Fischer, 121-170. Cambridge, Mass. and London: MIT Press.

Roose, Kenneth D. 1954. The economics of recession and revival; an interpretation of 1937-38. Yale studies in economics. Vol. 2. New Haven: Yale University Press.

Schwartz, Anna J. 2009. Origins of the financial market crisis of 2008. Cato Journal 29 (1) (winter): 19-23.

Taylor, John B. 2007. Housing and monetary policy. National Bureau of Economic Research, Inc, NBER Working Papers: 13682. http://www.nber.org/papers/w13682.pdf.

Temin, Peter. 1976. Did monetary forces cause the Great Depression? 1st ed. New York: Norton.

Tobin, James. 1970. [Comment on Tobin]: Rejoinder. The Quarterly Journal of Economics 84 (2) (May): 328-9. 1970. Money and income: Post hoc ergo propter hoc? The Quarterly Journal of Economics 84 (2) (May): 301-17.

1965. The monetary interpretation of history. The American Economic Review 55 (3) (June): 464-85.

Warburton, Clark. 1966. Depression, inflation, and monetary policy; selected papers, 19451953. Baltimore: Johns Hopkins Press.

White, Eugene Nelson. 1984. A reinterpretation of the banking crisis of 1930. Journal of Economic History 44 (1) (03): 119-38.

Wicker, Elmus. 1996. The banking panics of the Great Depression. Studies in monetary and financial history. New York: Cambridge University Press. 